\title{
Endosonographic Appearances of a Rare Duodenal Tumour, Brunner's Gland Hamartoma
}

\author{
Ikram Hussain ${ }^{a} \quad$ Malcolm Tan ${ }^{b}$ Meyyur Aravamudan Veeraraghavan ${ }^{c}$ \\ Lai Mun Wang ${ }^{d}$ Andrew Eu Boon Kwek ${ }^{\text {b }}$ \\ aDepartment of Gastroenterology, Khoo Teck Puat Hospital, Singapore, Singapore; \\ ${ }^{b}$ Department of Gastroenterology and Hepatology, Changi General Hospital, \\ Singapore, Singapore; 'Department of Medicine, Khoo Teck Puat Hospital, \\ Singapore, Singapore; dPathology, Department of Laboratory Medicine, Changi General \\ Hospital, Singapore, Singapore
}

\section{Keywords}

Brunner glands · Hamartoma - Gastrointestinal haemorrhage $\cdot$ Endosonography

\begin{abstract}
Brunner's gland hamartoma (BGH) is a rare sub-epithelial tumour of the duodenum, which may cause haemorrhagic or obstructive gastrointestinal symptoms. Their accurate histological diagnosis often remains elusive before resection. Although endoscopic ultrasonography (EUS) is considered an excellent modality to study lesions within the gastrointestinal wall, only a few reports have described endosonographic characteristics of BGHs. A reliable pre-resection diagnosis with EUS may not only allay fear of malignancy but may as well avert a major surgery for the patients. In this report, we present a rare case of a large BGH in a young female who presented with acute gastrointestinal bleeding. Here, the endosonographic features assuaged the concern for malignancy while aiding in complete and uneventful surgical resection of the tumour via a submucosal plane.




\section{Case Reports in Gastroenterology}

Case Rep Gastroenterol 2019;13:310-320

DOI: $10.1159 / 000501674$

(c) 2019 The Author(s). Published by S. Karger AG, Basel www.karger.com/crg

Hussain et al.: Endosonographic Appearances of a Rare Duodenal Tumour, Brunner's

Gland Hamartoma

\section{Introduction}

With less than 200 cases reported in the literature so far, Brunner's gland hamartoma $(\mathrm{BGH})$ is one of the rare benign intestinal tumours which is mostly encountered in the duodenum [1]. This tumour arises from hyperplastic or hamartomatous proliferations of Brunner's glands normally present in the submucosa of the duodenum. With increasing size, the tumour may result in pain, luminal obstruction, or/and upper gastrointestinal (GI) bleeding. Upon endoscopy, although BGHs are easily visible as sub-epithelial polypoidal lesions in the duodenal wall, the ascertainment of histopathology and source of origin remains challenging before resection. Due to its sub-epithelial location, mucosal bite biopsies are almost always inconclusive. Moreover, the cross-sectional imaging is often unable to decipher the origin and may at times confuse it with a malignant duodenal or pancreatic neoplasm.

Endoscopic ultrasonography (EUS) is considered an excellent imaging modality for the examination of sub-epithelial GI lesions. EUS can elicit the layer of origin, the internal contents, and the vascularity of deep-seated lesions while simultaneously paving the way for the acquisition of a tissue specimen. As BGHs are rare, only a few reports have described their EUS characteristics. In this report, we describe a case of a large duodenal BGH with a focus on its endosonographic appearances. In the same context, a review of the literature was conducted.

\section{Case Report}

A 43-year-old Chinese female was hospitalized with epigastric discomfort and multiple episodes of loose, black-coloured stools. There was no history of nausea or vomiting. She was apparently well until 3 days ago when symptoms started. She denied recent consumption of any analgesics (e.g., non-steroidal anti-inflammatory drugs), smoking or consumption of alcohol. There was no family history of GI disease. Physical examination revealed tachycardia (heart rate 113 beats per minute) but normal blood pressure. The abdomen was soft and nontender with no palpable masses, and there were no stigmata of chronic liver disease. Digital rectal examination did not elicit any stools. Initial blood investigations were only remarkable for the presence of normocytic, normochromic anaemia with a serum haemoglobin value of $7.5 \mathrm{~g} / \mathrm{dL}$ (normal range: 11.5-15.1). Renal and liver function tests were unremarkable.

After adequate intravenous fluid resuscitation and transfusion of one unit of red blood cells, an urgent upper GI endoscopy was performed. Intravenous proton-pump inhibitor (Pantoprazole) therapy, with a bolus of $80 \mathrm{mg}$ followed by an infusion at $8 \mathrm{mg} / \mathrm{h}$, was initiated before the endoscopy. During endoscopy, a large, sessile polyp was noted in the duodenal bulb which was causing partial luminal obstruction (Fig. 1). However, passage of the adult gastroscope (Olympus ${ }^{\circledR}$ GIF-H260) into the second part of the duodenum was possible, with only a slight amount of contact bleeding from the surface of the polyp. The surface of the polyp had superficial ulcerations, but without any adherent clot or visible vessel. Additionally, in the stomach, there were endoscopic features suggestive of gastritis, and the rapid urease test for the presence of Helicobacter pylori infection was positive. The mucosal biopsies from the duodenal polyps were non-diagnostic and only revealed granulation tissue with focal erosions. There were no dysplastic or malignant features. To investigate the lesion further, a computed tomographic scan with intravenous iodinated contrast (Omnipaque ${ }^{\mathrm{TM}} 350$ ) of the abdomen 


\section{Case Reports in Gastroenterology} \begin{tabular}{l|l}
\hline Case Rep Gastroenterol 2019;13:310-320 \\
\hline DOI: 10.1159/000501674 & $\begin{array}{l}\text { @ 2019 The Author(s). Published by S. Karger AG, Basel } \\
\text { www.karger.com/crg }\end{array}$
\end{tabular}

Hussain et al.: Endosonographic Appearances of a Rare Duodenal Tumour, Brunner's Gland Hamartoma

was subsequently performed. A single heterogeneously enhancing mass of large size $(2.4 \mathrm{~cm}$ $\times 2.4 \mathrm{~cm} \times 5.6 \mathrm{~cm}$ ) was seen in the proximal duodenum arising from its walls.

To evaluate this sub-epithelial lesion, an EUS was performed with a radial echoendoscope (GF-UE160-AL5, Olympus ${ }^{\circledR}$, Tokyo, Japan) attached with a balloon (Fig. 2, Fig. 3). A large (44 $\mathrm{mm}$ in maximum diameter), heterogeneous lesion with faint hypoechogenicity was identified in the duodenal bulb. The lesion arose from the 3rd echoic layer (consistent with submucosa). The 4th echoic layer representing the muscularis propria was not breached. The structure had a broad stalk (20 mm in length). The lesion contained several large anechoic areas with postacoustic enhancement which were consistent with cysts. Doppler views demonstrated multiple colour signals in the lesion (Fig. 4). In view of this apparent vascularity, fine needle aspiration was not performed. Based on the EUS findings of a submucosal tumour with cystic spaces and vascularity, the following differential diagnoses were considered: Brunner's gland tumour, pancreatic rest, and neuroendocrine tumour.

Due to the broad base of the lesion and the constrained physical space in the duodenal bulb, which might have precluded manoeuvring of endoscopic accessories, an attempt with endoscopic resection was considered difficult. Furthermore, there was an apparent risk of haemorrhagic complications with endoscopic resection due to multiple colour Doppler signals. Consequently, the polyp was surgically approached with a longitudinal duodenotomy, and complete resection was carried out up to the submucosal layer. No other intra-abdominal abnormality was found on routine examination. The patient had an uneventful post-operative recovery and was discharged 10 days later. No endoscopic recurrence of the duodenal polyp was observed after 6 months.

The pathological sample contained a large (measuring $6.0 \mathrm{~cm} \times 3.0 \mathrm{~cm} \times 2.0 \mathrm{~cm}$ ), lobulated polypoidal mass with superficial ulcerations (Fig. 5, Fig. 6). Deep margins of the tumour were limited to the submucosa. Histopathological examination showed multiple lobules of hyperplastic Brunner's glands separated by hypertrophied smooth muscle fibres, consistent with the diagnosis of a BGH, and they were without dysplastic or malignant features.

\section{Discussion}

Brunner's glands are branched acinotubular glands which are anatomically positioned in the submucosa and deep mucosa of the duodenum and rarely in the pylorus and jejunum. The alkaline viscous mucous from these glands counteracts the acidic chyme from the stomach, thus preventing acidic mucosal damage in the duodenum while also creating a conducive alkaline $\mathrm{pH}$ for intestinal enzymes. Small-sized, innocuous hyperplastic proliferations (defined as $1 \mathrm{~cm}$ or less in size) of Brunner's glands are commonly encountered on routine endoscopic examination. But, proliferation into a BGH is a rare event. For example, in a large autopsy series, the overall incidence of all benign duodenal tumours was $0.008 \%$, and only $10.6 \%$ of these benign duodenal lesions were from Brunner's glands [2]. Most patients are middle-aged patients where BGH may present with dyspepsia, epigastric pain, upper GI bleeding or obstruction. The proximal duodenum is the most common location for such lesions [3], and the incidence of such tumours decreases in a caudal direction. The underlying pathogenesis of such uncontrolled hamartomatous growth is unclear, though several causative factors (e.g., $H$. pylori infection, chronic pancreatitis and local irritation) have been postulated [4,5]. 


\section{Case Reports in Gastroenterology}

Case Rep Gastroenterol 2019;13:310-320

DOI: $10.1159 / 000501674$

(c) 2019 The Author(s). Published by S. Karger AG, Base www.karger.com/crg

Hussain et al.: Endosonographic Appearances of a Rare Duodenal Tumour, Brunner's

Gland Hamartoma

In most situations, an endoscopically conspicuous polypoidal lesion is identified in the duodenum, whose diagnosis remains unclear before resection. The sub-epithelial tumour is covered with intact or ulcerated mucosa. The endoscopic appearances are not characteristic for BGH. Other duodenal tumours, such as adenomas, neuroendocrine tumours, GI stromal tumours, pancreatic rests and pancreatic and ampullary neoplasms, may be indistinguishable in endoscopic appearances from the BGH. Furthermore, the endoscopic mucosal biopsies are of low yield, especially because of the submucosal location of a BGH. Similarly, the radiological imaging modalities, like computed tomography examination, may also not aid in the diagnosis of a BGH; however, the presence of extramural extension or distant metastasis will not be consistent with this tumour.

EUS is an excellent imaging modality to assess GI sub-epithelial lesions. Only a few cases have reported the endosonographic appearances of BGHs (Table 1) [6-18]. The lesions arise from deep mucosa or submucosa and do not breach the muscularis propria layer. The echogenicity may vary from hypoechoic to hyperechoic depending on the amount of fibro-muscular tissues in the stroma. More often, a heterogeneous echogenicity within the lesion is observed. Homogenous appearances are more consistent with Brunner's gland adenoma rather than hamartoma [19]. Since Brunner's glands can normally be present inside the duodenal wall but outside the tumour, the boundaries of the lesion are often indistinct on EUS. Several anechoic dilated areas are visible inside the tumour consistent with Brunner's cysts on histopathology. Only a few reports have commented on the prominent vascularity of the lesions on Doppler ultrasonography [7]. Abundant Doppler signals were observed in our case. As a BGH is composed of benign cellular components, EUS-guided fine needle aspiration is unlikely to yield a diagnosis. Despite having no help from tissue diagnosis, the endosonographic appearances alone may suffice to confidently diagnose a BGH and to rule out other differential diagnoses of duodenal sub-epithelial lesions (Table 2).

The only therapy for a BGH is resection which provides definitive cure. Endoscopic resection of such tumours is increasingly being reported, although it is often challenging due to a physically constrained duodenal lumen. Surgical resection with duodenotomy generally is sufficient for complete removal of the tumour; however, pancreatoduodenectomy has also been performed in view of the uncertainty of a pre-operative diagnosis. In our case, the accurate description on EUS was helpful in avoiding a radical surgery. Given the rarity of the disease, there is no consensus to guide follow-up. Endosonographic follow-up is not warranted as the BGHs are benign lesions with almost no risk of breaching the muscularis propria. No endoscopic recurrence was observed in our case 6 months after resection.

The present case highlights the importance of considering BGH in the differential diagnosis of duodenal tumours. The report also describes the peculiar endosonographic features of a BGH, which may guide appropriate resection.

\section{Statement of Ethics}

Patient consent has been obtained, no patient identifiers have been used, and the case was anonymised. 


\section{Case Reports in Gastroenterology}

Case Rep Gastroenterol 2019;13:310-320

DOI: $10.1159 / 00050167$

(C) 2019 The Author(s). Published by S. Karger AG, Base www.karger.com/crg

Hussain et al.: Endosonographic Appearances of a Rare Duodenal Tumour, Brunner's

Gland Hamartoma

\section{Disclosure Statement}

The authors have no disclosures to make directly related to the study and have no conflict of interest.

\section{Funding Sources}

The authors declare that no funding was received for the preparation of this manuscript.

\section{Author Contributions}

All authors contributed to the preparation, review and editing of the manuscript.

\section{References}

1 Stewart ZA, Hruban RH, Fishman EF, Wolfgang CL. Surgical management of giant Brunner's gland hamartoma: case report and literature review. World J Surg Oncol. 2009 Sep;7(1):68.

2 Osborne R, Toffler R, Lowman RM. Brunner's gland adenoma of the duodenum. Am J Dig Dis. 1973 Aug;18(8):689-94.

3 Levine JA, Burgart LJ, Batts KP, Wang KK. Brunner's gland hamartomas: clinical presentation and pathological features of 27 cases. Am J Gastroenterol. 1995 Feb;90(2):290-4.

4 Kovacević I, Ljubicić N, Cupić H, Doko M, Zovak M, Troskot B, et al. Helicobacter pylori infection in patients with Brunner's gland adenoma. Acta Med Croatica. 2001;55(4-5):157-60.

5 Stolte M, Schwabe H, Prestele H. Relationship between diseases of the pancreas and hyperplasia of Brunner's glands. Virchows Arch A Pathol Anat Histol. 1981;394(1-2):75-87.

6 Inai M, Sakai M, Kajiyama T, Imada-Shirakata Y, Kin G, Inoue K, et al. Endosonographic characterization of duodenal elevated lesions. Gastrointest Endosc. 1996 Dec;44(6):714-9.

7 Ueno N, Tomiyama T, Tano S, Aizawa T, Nagamine N, Kihira K, et al. A case of Brunner's gland hyperplasia: endoscopic color Doppler ultrasonographic findings. Endoscopy. 1997 Jan;29(1):51.

8 Weisselberg B, Melzer E, Liokumovich P, Kurnik D, Koller M, Bar-Meir S. The endoscopic ultrasonographic appearance of Brunner's gland hamartoma. Gastrointest Endosc. 1997 Aug;46(2):176-8.

9 Block KP, Frick TJ, Warner TF. Gastrointestinal bleeding from a Brunner's gland hamartoma: characterization by endoscopy, computed tomography, and endoscopic ultrasound. Am J Gastroenterol. 2000 Jun;95(6):1581-3.

10 Changchien CS, Hsu CC, Hu TH. Endosonographic appearances of Brunner's gland hamartomas. J Clin Ultrasound. 2001 May;29(4):243-6.

11 Kaufman DJ, Al Kharrat H, Weiss S, Robert M, Topazian M. EUS-guided endoscopic removal of a large Brunner's gland hamartoma. Gastrointest Endosc. 2003 Aug;58(2):313-4.

12 George B, Srikureja W, Shah A, Chacko A. Endonography findings in brunneroma. Indian J Gastroenterol. 2008 Jan-Feb;27(1):45.

13 Babich JP, Klein J, Friedel DM. Endoscopic removal of a brunneroma with EUS guidance. South Med J. 2010 Mar;103(3):250-2.

14 Carboni F, Valle M, Garofalo A, Mariantonia C. Laparoscopic excision of a symptomatic brunneroma. Am Surg. 2011 Feb;77(2):E37-8.

15 Stoos-Veic T, Tadic M, Aralica G. EUS-FNA of Brunner's gland hamartoma: a case report. Cytopathology. 2013 Jun;24(3):194-6.

16 Barbeiro S, Martins CA, Marcos P, Gonçalves C. Brunner's gland hamartoma - a rare cause of upper gastrointestinal bleeding. GE Port J Gastroenterol. 2015 Sep;22(6):283-5.

17 Hsieh WY, Chen PH, Hou MC. A duodenal tumor that causes partial obstruction. Gastroenterology. 2016 Jan;150(1):e9-10. 


\section{Case Reports in Gastroenterology}

Case Rep Gastroenterol 2019;13:310-320

(C) 2019 The Author(s). Published by S. Karger AG, Basel www.karger.com/crg

Hussain et al.: Endosonographic Appearances of a Rare Duodenal Tumour, Brunner's

Gland Hamartoma

18 Peloso A, Viganò J, Vanoli A, Dominioni T, Zonta S, Bugada D, et al. Saving from unnecessary pancreaticoduodenectomy. Brunner's gland hamartoma: case report on a rare duodenal lesion and exhaustive literature review. Ann Med Surg (Lond). 2017 Mar;17:43-9.

19 Yadav D, Hertan H, Pitchumoni CS. A giant Brunner's gland adenoma presenting as gastrointestinal hemorrhage. J Clin Gastroenterol. 2001 May-Jun;32(5):448-50.

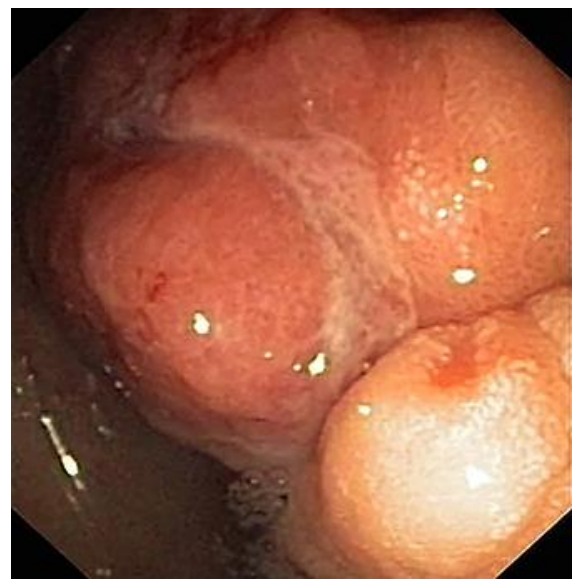

Fig. 1. The large sessile polyp arising from the anterior-superior wall of the duodenal bulb. Superficial ulcerations over its surface are visible. 


\section{Case Reports in Gastroenterology}

Case Rep Gastroenterol 2019;13:310-320

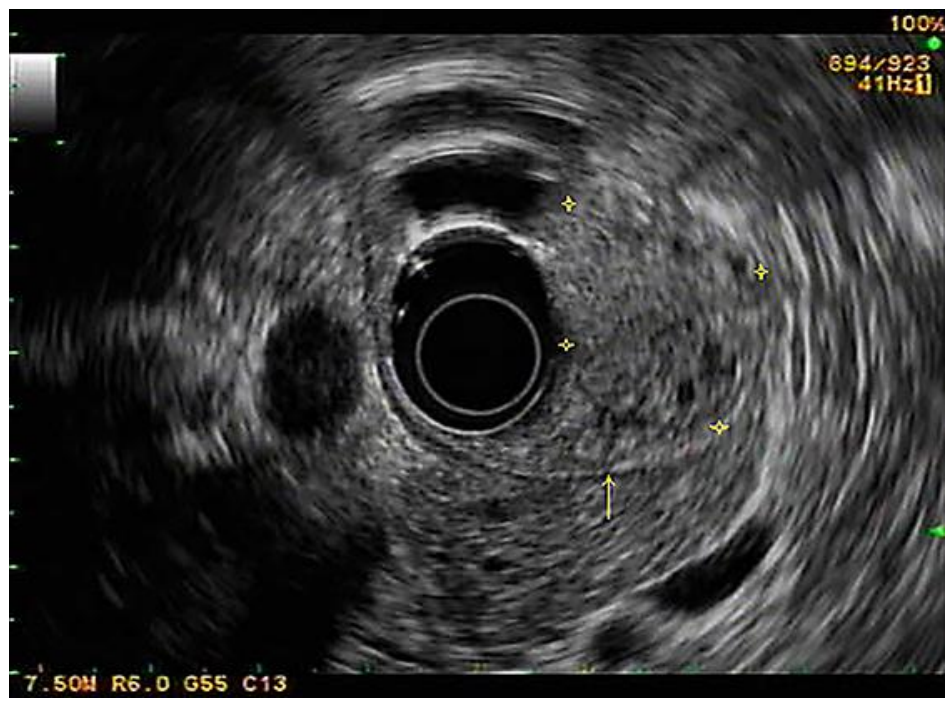

Fig. 2. A round lesion (depicted with yellow stars) of heterogeneous echogenicity is visible in the mucosal and submucosal layers of the duodenum on radial EUS (7.5 MHz). The muscularis propria (yellow arrow) is not breached.

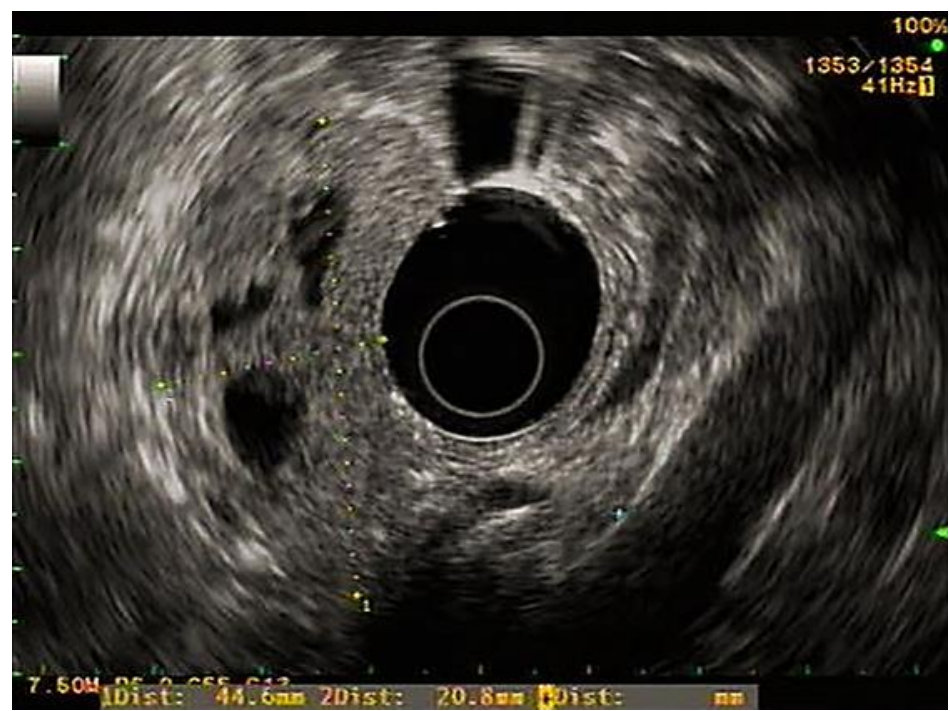

Fig. 3. Multiple anechoic areas (consistent with cysts) are visible inside the lesion on higher magnification. 


\section{Case Reports in Gastroenterology}

Case Rep Gastroenterol 2019;13:310-320

Hussain et al.: Endosonographic Appearances of a Rare Duodenal Tumour, Brunner's

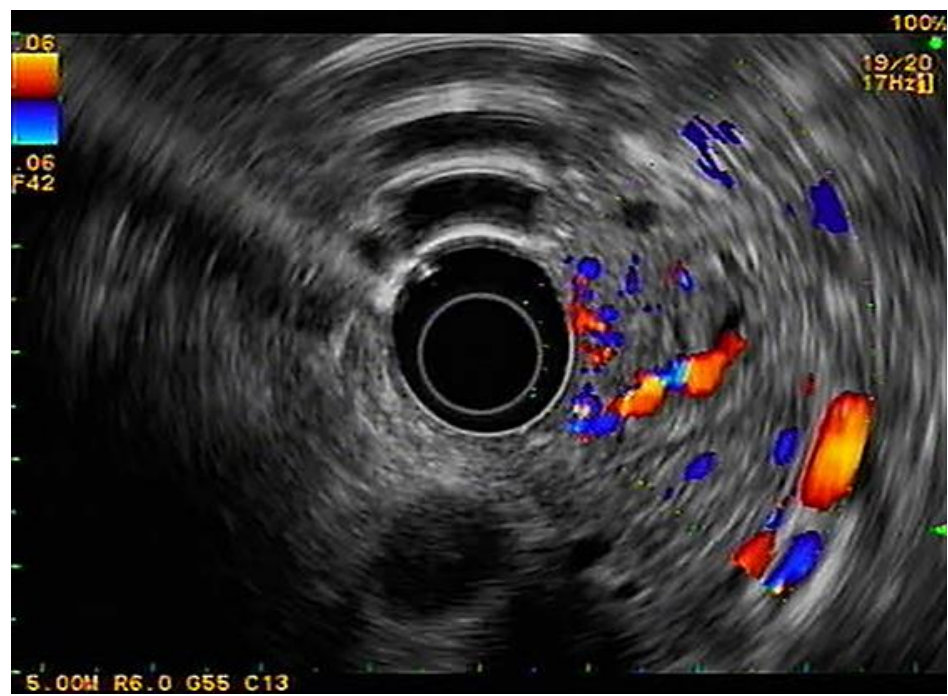

Fig. 4. Multitudes of vascular signals are seen inside the lesion on Doppler imaging.

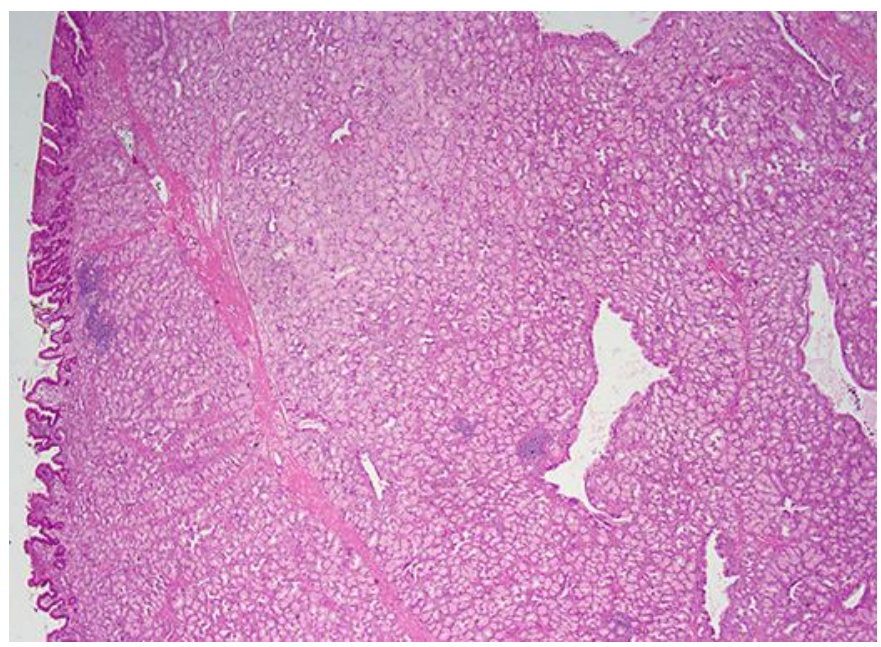

Fig. 5. HE section of BGH at low magnification $(\times 20)$ showing submucosal expansion by lobules of hyperplastic Brunner's glands with overlying gastric epithelium. 


\section{Case Reports in Gastroenterology}

Case Rep Gastroenterol 2019;13:310-320

(c) 2019 The Author(s). Published by S. Karger AG, Basel www.karger.com/crg

Hussain et al.: Endosonographic Appearances of a Rare Duodenal Tumour, Brunner's Gland Hamartoma

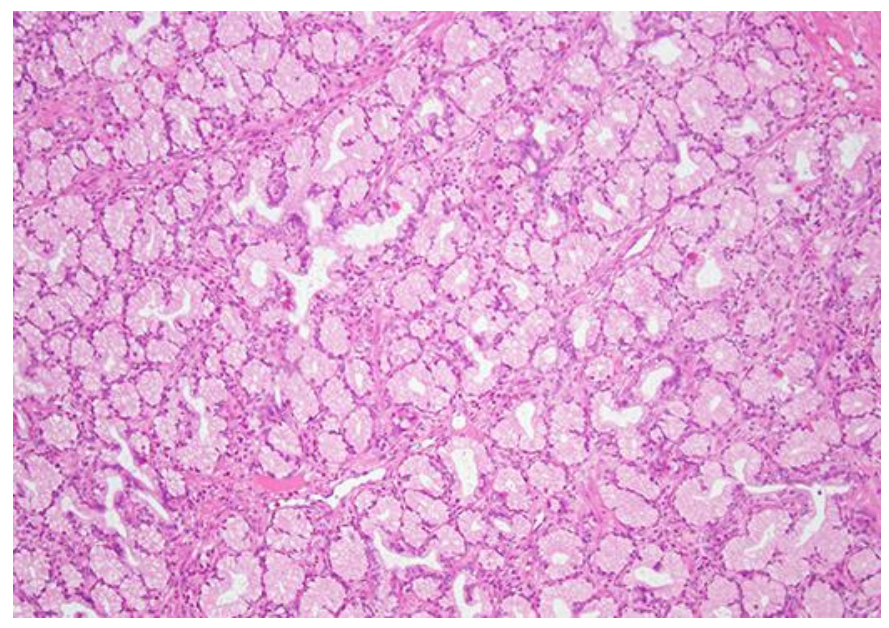

Fig. 6. BGH at higher magnification $(\times 100)$ illustrating multiple lobules of Brunner's glands characterized by cuboidal to columnar cells with clear cytoplasm. No cellular atypia is identified. 


\section{Case Reports in Gastroenterology}

\begin{tabular}{l|l}
\hline Case Rep Gastroenterol 2019;13:310-320 \\
\hline DOI: 10.1159/000501674 & $\begin{array}{l}\text { @ 2019 The Author(s). Published by S. Karger AG, Basel } \\
\text { www.karger.com/crg }\end{array}$ \\
\hline
\end{tabular}
www.karger.com/crg

Hussain et al.: Endosonographic Appearances of a Rare Duodenal Tumour, Brunner's

Gland Hamartoma

Table 1. Studies describing detailed EUS features of BGHs

\begin{tabular}{|c|c|c|c|c|c|c|c|}
\hline $\begin{array}{l}\text { Year } \\
\text { [ref.] }\end{array}$ & Authors & Size on EUS & $N$ & EUS-imaging features & EUS FNA & Doppler signals & Treatment \\
\hline $1996[6]$ & $\begin{array}{l}\text { Inai } \\
\text { et al. }\end{array}$ & Not provided & 1 & $\begin{array}{l}\text { Heterogeneous echogenicity; } \\
\text { in mucosa and submucosa; } \\
\text { unclear borders and margins; } \\
\text { cystic lesions inside the tumour }\end{array}$ & Not done & Not reported & Not reported \\
\hline 1997 [7] & $\begin{array}{l}\text { Ueno } \\
\text { et al. }\end{array}$ & Not provided & 1 & $\begin{array}{l}\text { Subtle hypoechogenicity; } \\
\text { origin in submucosa; } \\
\text { cystic lesions inside the tumour }\end{array}$ & Not done & $\begin{array}{l}\text { Abundant } \\
\text { colour signals }\end{array}$ & $\begin{array}{l}\text { Surgical } \\
\text { resection }\end{array}$ \\
\hline $1997[8]$ & $\begin{array}{l}\text { Weisselberg et } \\
\text { al. }\end{array}$ & Not provided & 1 & $\begin{array}{l}\text { Variable echogenicity; } \\
\text { in mucosa and submucosa; } \\
\text { cystic lesions inside the tumour }\end{array}$ & Not done & Not reported & $\begin{array}{l}\text { Surgical } \\
\text { resection }\end{array}$ \\
\hline 2000 [9] & $\begin{array}{l}\text { Block } \\
\text { et al. }\end{array}$ & $2.4 \times 3.0 \mathrm{~cm}$ & 1 & $\begin{array}{l}\text { Mixed echogenicity; } \\
\text { in submucosa }\end{array}$ & Not done & Not reported & $\begin{array}{l}\text { Surgical } \\
\text { resection }\end{array}$ \\
\hline $\begin{array}{l}2001 \\
{[10]}\end{array}$ & $\begin{array}{l}\text { Changchien et } \\
\text { al. }\end{array}$ & $\begin{array}{l}\text { 1st case: } \\
2.7 \mathrm{~cm} \\
2 \mathrm{nd} \text { case: } \\
1.4 \mathrm{~cm}\end{array}$ & 2 & $\begin{array}{l}\text { 1st case: } \\
\text { Heterogeneous and hyperechoic; } \\
\text { in mucosa and submucosa; } \\
\text { cystic lesions inside the tumour } \\
\text { 2nd case: } \\
\text { Echogenicity intermediate between } \\
\text { muscularis propria and mucosal layers; } \\
\text { in mucosal layer; } \\
\text { cystic lesions inside the tumour }\end{array}$ & Not done & Not reported & $\begin{array}{l}\text { 1st case: } \\
\text { Surgical } \\
\text { resection } \\
\text { 2nd case: } \\
\text { Endoscopic } \\
\text { resection }\end{array}$ \\
\hline $\begin{array}{l}2003 \\
{[11]}\end{array}$ & $\begin{array}{l}\text { Kaufman } \\
\text { et al. }\end{array}$ & Not provided & 1 & $\begin{array}{l}\text { Homogenous and hyperechoic; } \\
\text { in submucosa; } \\
2 \text { cystic lesions inside the tumour }\end{array}$ & Not done & $\begin{array}{l}\text { No vascular signals } \\
\text { in the stalk of } \\
\text { tumour }\end{array}$ & $\begin{array}{l}\text { Endoscopic } \\
\text { resection }\end{array}$ \\
\hline $\begin{array}{l}2008 \\
{[12]}\end{array}$ & $\begin{array}{l}\text { George } \\
\text { et al. }\end{array}$ & Not provided & 1 & $\begin{array}{l}\text { Uniformly hyperechoic (confused with lipoma); } \\
\text { in submucosa }\end{array}$ & Not done & Not reported & $\begin{array}{l}\text { Endoscopic } \\
\text { resection }\end{array}$ \\
\hline $\begin{array}{l}2010 \\
{[13]}\end{array}$ & $\begin{array}{l}\text { Babich } \\
\text { et al. }\end{array}$ & $1.1 \mathrm{~cm} \times 1.0 \mathrm{~cm}$ & 1 & $\begin{array}{l}\text { Predominantly isoechoic; } \\
\text { in submucosa; } \\
\text { central cystic lesion in the tumour }\end{array}$ & Not done & Not reported & $\begin{array}{l}\text { Endoscopic } \\
\text { resection }\end{array}$ \\
\hline $\begin{array}{l}2011 \\
{[14]}\end{array}$ & $\begin{array}{l}\text { Carboni } \\
\text { et al. }\end{array}$ & $3.5 \mathrm{~cm}$ & 1 & $\begin{array}{l}\text { Mixed echogenicity; } \\
\text { in submucosa }\end{array}$ & Not done & Not reported & $\begin{array}{l}\text { Surgical } \\
\text { resection }\end{array}$ \\
\hline $\begin{array}{l}2013 \\
{[15]}\end{array}$ & $\begin{array}{l}\text { Stoos-Veic } \\
\text { et al. }\end{array}$ & $4 \mathrm{~cm} \times 6.3 \mathrm{~cm}$ & 1 & $\begin{array}{l}\text { Hypoechoic; } \\
\text { probably originated in muscularis propria; } \\
\text { cystic lesions inside the tumour }\end{array}$ & $\begin{array}{l}\text { FNA yielded } \\
\text { benign epithelial } \\
\text { cells (non-diag- } \\
\text { nostic) }\end{array}$ & Not reported & $\begin{array}{l}\text { Surgical } \\
\text { resection }\end{array}$ \\
\hline $\begin{array}{l}2015 \\
{[16]}\end{array}$ & $\begin{array}{l}\text { Barbeiro } \\
\text { et al. }\end{array}$ & $1.1 \mathrm{~cm}$ & 1 & $\begin{array}{l}\text { Hypoechoic; } \\
\text { in submucosa }\end{array}$ & Not done & Not reported & $\begin{array}{l}\text { Endoscopic } \\
\text { resection }\end{array}$ \\
\hline $\begin{array}{l}2016 \\
{[17]}\end{array}$ & $\begin{array}{l}\text { Hsieh } \\
\text { et al. }\end{array}$ & $1.86 \mathrm{~cm} \times 1.08 \mathrm{~cm}$ & 1 & $\begin{array}{l}\text { Isoechoic; } \\
\text { in submucosa; } \\
\text { cystic lesions inside the tumour }\end{array}$ & Not done & Not reported & $\begin{array}{l}\text { Endoscopic } \\
\text { resection }\end{array}$ \\
\hline $\begin{array}{l}2017 \\
{[18]}\end{array}$ & $\begin{array}{l}\text { Peloso } \\
\text { et al. }\end{array}$ & $4 \mathrm{~cm}$ & 1 & $\begin{array}{l}\text { Mixed echogenicity; } \\
\text { in submucosa; } \\
\text { no clear plane between tumour and } \\
\text { pancreatic head }\end{array}$ & Not done & Not reported & $\begin{array}{l}\text { Surgical } \\
\text { resection }\end{array}$ \\
\hline Our case & $\begin{array}{l}\text { Hussain } \\
\text { et al. }\end{array}$ & $4.4 \mathrm{~cm}$ & 1 & $\begin{array}{l}\text { Faintly hypoechoic; } \\
\text { in mucosa and submucosa; } \\
\text { multiple cystic lesions in the tumour }\end{array}$ & Not done & $\begin{array}{l}\text { Multiple } \\
\text { vascular signals }\end{array}$ & $\begin{array}{l}\text { Surgical } \\
\text { resection }\end{array}$ \\
\hline
\end{tabular}


Gastroenterology

Hussain et al.: Endosonographic Appearances of a Rare Duodenal Tumour, Brunner's

Gland Hamartoma

Table 2. EUS characteristics of sub-epithelial duodenal tumours

\begin{tabular}{lllll}
\hline Lesion & $\begin{array}{l}\text { Echo layer of } \\
\text { origin }\end{array}$ & EUS features & $\begin{array}{l}\text { Fine needle } \\
\text { aspiration }\end{array}$ & Clinical characteristics \\
\hline $\begin{array}{l}\text { Gastrointestinal } \\
\text { stromal tumour (GIST) }\end{array}$ & $\begin{array}{l}\text { 4th or rarely } \\
\text { 2nd }\end{array}$ & $\begin{array}{l}\text { Variable echogenicity (usually } \\
\text { hypoechoic); large lesions may have cystic } \\
\text { components; lymphadenopathy in high-risk } \\
\text { tumours }\end{array}$ & Spindle cells & $\begin{array}{l}\text { Has malignant potential; } \\
\text { treatment depends on the stage } \\
\text { of disease }\end{array}$ \\
\hline $\begin{array}{l}\text { Neuroendocrine } \\
\text { tumour }\end{array}$ & $\begin{array}{l}\text { 1st or 2nd } \\
\text { layer }\end{array}$ & Hypoechoic, may potentially breach all layers & Not required & $\begin{array}{l}\text { Has malignant potential; } \\
\text { endoscopic biopsies may yield } \\
\text { diagnosis }\end{array}$ \\
\hline Lipoma & 3rd layer & Hyperechoic, well circumscribed & Not required & $\begin{array}{l}\text { Benign; resection is curative in } \\
\text { symptomatic patients }\end{array}$ \\
\hline $\begin{array}{llll}\text { Pancreatic rest } \\
\text { 3rd layer }\end{array}$ & $\begin{array}{l}\text { Hypoechoic, anechoic tubular } \\
\text { structures inside consistent with } \\
\text { rudimentary ducts }\end{array}$ & Not required & $\begin{array}{l}\text { Requires resection in } \\
\text { symptomatic cases }\end{array}$ \\
\hline $\begin{array}{l}\text { Brunner's gland } \\
\text { hamartoma }\end{array}$ & 2nd or 3rd & $\begin{array}{l}\text { Heterogeneous echogenicity; } \\
\text { no breach of muscularis propria; anechoic or } \\
\text { cystic areas inside the tumour; prominent } \\
\text { vascular signals }\end{array}$ & Not required & $\begin{array}{l}\text { Benign; resection in } \\
\text { symptomatic patient is curative }\end{array}$ \\
\hline
\end{tabular}

